\title{
Climate change science: a historical outline
}

\author{
Medani P Bhandari \\ Department of Natural Resource \& Environment / Sustainability Studies, Akamai University, USA
}

Correspondence: Medani P Bhandari, PhD is Professor at the Department of Natural Resource \& Environment / Sustainability Studies, Akamai University, Hawaii, USA, Tel 240-505-1469, Email medani.bhandari@gmail.com

Received: November 15, 2017 | Published: February 08, 2018

Copyright@ 2018 Bhandari. This is an open access article distributed under the terms of the Creative Commons Attribution License, which permits unrestricted use, distribution, and reproduction in any medium, provided the original author and source are credited.

\begin{abstract}
This paper provides a brief overview of the scientific developments regarding climate change, showing how the science evolved slowly, however by the end of the $20^{\text {th }}$ century, it began to predict problems. This paper is based on secondary published material. The purpose of the paper is to provide a knowledge base on climate change, science, and provide the list of most important references with additional notes.
\end{abstract}

\section{Introduction}

"Philosophy of science without history of science is empty; history of science without philosophy of science is blind". ${ }^{1}$

"Knowledge and power meet in one; for where the cause is not known, the effect cannot be produced. Nature to be commanded must be obeyed; and that which in contemplation is as the cause is in operation as the rule'"Francis Bacon (1561-1626)

The climate change science has a relatively long history. The word climate is derived from the Greek word Klima, which meant "inclination, the supposed slope of the earth toward the pole." Several editions of The Encyclopedia Britannica make essentially the same statement but add, "or the inclination of the earth's axis". ${ }^{2-}$ ${ }^{4}$ The concept of science and technology began in the Greek era. Technology, which came through the legacy of the term "techne, " was a major product of Greek era. Techne was used to illustrate the rational method to achieve a perceived goal or objective. "For Aristotle, techne was a very particular kind of knowledge...this was a kind of knowledge associated with people who were bound to necessity. ${ }^{6}$ This indicates that during the Greek era, techne was not as we understand it today, but was a research system or knowledge production to attain a certain goal. "Heidegger identifies Plato's articulation of techne as the foundation upon which contemporary technology builds". ${ }^{7}$ However, Heidegger's notion is concentrated to articulate the anti-technology theses, ${ }^{8}$ which is largely in academic discussion. Heidegger himself did not accept he was against the technological enhancement. The notion of technology, which developed throughout human history, is backed by the need of human society. In this connection, ${ }^{9}$ nicely depicts the situation.

Since the dawn of the nineteenth century, the world has experienced at least three major technological revolutions which have transformed the way humans live, work, and play, while providing the technological infrastructure for the development of modern science, and also changing the meaning and experience of the weather and climate. Following an extremely long (but not at all static) period of human experience before 1800 that may be broadly characterized as agricultural or pastoral, the rate of technological change accelerated dramatically with two major technological eras - the industrial and the post-industrial --occurring in the past two centuries. These revolutions have fundamentally altered humanity's interaction with nature, both in the sense of the built environment, which mediates our perceptions of the weather, and in the sense of instruments that transform scientists' ability to observe, analyze, and predict it. ${ }^{9}$

The climate change detection was only possible through the technological enhancement and use of enhanced tools to detect the change. The Greek began to explore the position of the Earth and atmospheric variation through Geology and Geography (Geology: Greek meaning Earth and its speed and Geography: "ge" for earth and "grapho" for "to write"); from where the exploration of climate variation and change came into the research agenda. The concern about the environmental change can be seen from the Greek Era; however, it was only within a certain group of people. The geological and geographical study of the Earth's system paved the ground for research on scenarios of climate variation; these are the oldest disciplines of the academic world. Longwell ${ }^{2}$ examines the root of the geological exploration - the first step in the detection of climate change.

Longwell ${ }^{2}$ states that:

"A current textbook of Geology states categorically that the word climate commemorates one of the oldest scientific discoveries, that the earth's axis is inclined to the ecliptic. Which of these two widely different interpretations has the better basis.".

He further says that the concept of climate was to identify the Earth's position and originator including Hipparchus, of the second century B.C.; Eratosthenes, of the third century B.C.; Ptolemy of Alexandria 
(mathematician and astronomer of the second century A.D) and others. The pioneers saw that a change in latitude means a change in atmospheric conditions as well as in length of day.... Probably the present meaning of climate developed gradually; but it is significant that divisions into torrid, temperate, and frigid zones still are made formally by parallels of latitude, although climatic belts in the modern sense are highly irregular in form. ${ }^{2}$

Change of the atmosphere condition directly relates with what we understand about the global climate today.

\section{What is climate change and why it is important?}

"Climate change is, by definition, detected when a statistically significant variation in mean climate, or in its variability, persists for an extended period (typically 30 years)"; ${ }^{10}$ the climate system is a complex, interactive system consisting of the atmosphere, land surface, snow and ice, oceans and other bodies of water, and living things. The atmospheric component of the climate system most obviously characterizes climate; climate is often defined as average weather'. Climate is usually described in terms of the mean and variability of temperature, precipitation and wind over a period of time, ranging from months to millions of years (the classical period is 30 years $)^{11} \ldots$ and Climate is generally defined as average weather, and as such, climate change and weather are intertwined. Observations can show that there have been changes in weather, and it is the statistics of changes in weather over time that identifies climate change. While weather and climate are closely related, there are important differences. ${ }^{11}$

To come up with this definition, several scientists have developed various tools and technologies and applied them to compare statistics over centuries to explore the truth that climate change is happening; however, where statistical history is not available, it remains unavoidable. The human civilization developed as a process along with the innovation of science and technology. The following paragraphs provide a brief outline of such a development process in major five geological eras.

\section{The concept is not new}

Paleolithic before 10,000 BCE: human muscle was the energy; stone and animal bone was used for human survival and the artifact was sharp stone. Similarly, in the Eco-techniques era from 10,000 BCE to $1750 \mathrm{AD}$, people developed the technique to use water and wind as energy. They produced wood, animal leather and cloth to protect the body and developed the Clipper Ship, Water Wheel and Violin. This helped human civilization enter a new way of life such as agriculture, Pastoralists and Artisans.

The Paleo-technic era (1750-1930) holds the fast forward development scenario in technological enhancement and application. With the use of coal and iron as material and the steam engine as energy, this era accelerated human domination on the natural system. The products of this era are the railroads, factories and bridges, which lead human lives toward a comfortable lifestyle. As a development process, it leads to mass production in agriculture and industries. However, as a consequence, the natural environment rapidly deteriorated through the use of chemical fertilizers and pesticides for mass crop production and emissions in the environment through factories.
The neo-technic era from 1930 to 2000 followed the same development process in a more sophisticated way. The major energy achievement of this era was electricity, oil and nuclear power. The innovation and application of aluminum and plastic, as well as the development of automobiles and airplanes for transportation has massively changed the human living style (mostly in the Western world). The impact on global climate became most visible in this era. The innovation of high-tech production of toxic chemicals, emissions into the atmosphere and mass consumption of goods and services were the major characteristics of this era.

However, in the $21^{\text {st }}$ century, the eco-technic era shows some new scenarios on this trend, where people began to realize the serious consequences of climate change caused by anthropogenic activities. At the lowest level, people have been exploring energy sources that will have the least impact on global climate. Investment in renewable energy such as the use of sunlight, wind and water for energy generation are a few examples of this kind. Similarly, the encouragement and initiation of the generalpublic toward the use of biodegradable, recyclable and reusable products is taking place on a small scale but is increasing (e.g. the concept of LEAD certified buildings, the ban of plastic bag use in Bangladesh and other countries). Likewise, searching for the product that has low impact on local and global climate, searching for natural products, using rechargeable products and increases in using compost manure in organic farming are some good steps of the $21^{\text {st }}$ century to minimize the impact on climate change. ${ }^{3}$ There is a growing trend of knowledge about climate change from the general public level to the national and international level.

In connecting the historical account of climate science, Karl Marcus Kriesel $^{12}$ notes that the writings of Charles Lous Joseph de Secondat Baron De La Brede et de Montesquieu (1689-1755, French jurist and political philosopher) was the first scientist who examined the effect of the physical environment upon societies and political systems produced by it, have been widely interpreted as being environmentalist or deterministic. ${ }^{12}$ Kriessel examines Montesquieu's contribution or role in bringing together the physical environment and the non- physical societal attributes as customs, manners, morals and tradition, which combined, produce a particular political or governmental system (557). Kriessel cites Platt (1948) in explanation of environmental determinism, where he states:

Determinism...refers to the idea to that everything in human life is caused inevitably by previous events or conditions. Extreme environmentalism refers to the idea that everything in human life is caused by the natural environment; and mild environmentalism refers to the idea that human life should be viewed as under the direct influence of the natural environment. ${ }^{12}$

Montesquieu's view, which was written in The Spirit of the Laws, summarizes that physical environment has a direct impact on human society. Montesquieu's major focus was to explain how mankind is influence by the biophysical and socio-cultural and politico-economic environment. Kriessel cites Montesquieu as:

Mankind are influenced by various causes: by the climate, by the religion, by the laws, by the maxims of government, by precedents, morals, and customs; whence is formed a general spirit of nations. In proposition as, in every country, and one of these causes acts with more force, the other in the same degree are weakened. Nature and the climate rule all most over the savage; customs govern the Chinese; 
the laws tyrannize in Japan; moral had formerly all their influence at Sparta; maxims of government, and the ancient simplicity of manners, once prevailed at Rome. ${ }^{12}$

These theses of Montesquieu as illustrated by Kriese $1^{12}$ clearly indicate that concern of climate change was firmly rooted in the academic and philosophical arena of the $16^{\text {th }}$ and $17^{\text {th }}$ centuries, which took a long time to verify, and only then with the application of technological tools that did not materialize until the $20^{\text {th }}$ century.

Likewise, James Rodger Fleming ${ }^{3}$ provides a brief chronology of how epistemology of climate science developed. Fleming cites (1998:1-16 and in presentation 1-24):

Aristotle: The same parts of the Earth are not always moist or dry, but they change accordingly as rivers come into existence and dry up... The principle and cause of these changes is that the interior of the earth grows and decays, like the bodies of plants and animals.

Theophrastus (successor of Aristotle): If... the winters are more severe, and more snow falls than formerly.... It follows that the monsoon has greater duration. Is it possible for humans to change the climate? Yes! through deforestation and irrigation.

Jean-Baptiste Dubos (l'Abbé Du Bos 1670-1742): Who noted Genius is not born in every climate. Dubos did not directly explain about the biophysical environment of the Earth but provided the relationship of human and climate.

David Hume ${ }^{13}$ : As the science of man is the only solid foundation for the other sciences, so the only solid foundation we can give this science itself must be laid on experience and observation". Fleming "Hume believed that the moderation of the climate had been caused by the gradual advance of cultivation in the nations of Europe".

"Allowing, therefore, this remark (of Du Bos) to be just that Europe is becoming warmer than formally; how can be account for it? Plainly, by no other method, than by supposing that the land us at present much better cultivated, and that the woods are cleared, which formerly threw a shade upon the earth and kept the rays of the sun from penetrating to it".

Hume had no tools as we have today to measure the impact of warming climate but his vision of far sightedness certainly gives future tendency of the climate change the world is facing today.

..."We want... [an index of climate] for all the States, and the work should be repeated once or twice in a century, to show the effect of clearing and culture towards thechanges of climate).

\section{Thomas Jefferson fully aware of climate change:}

Thomas Jefferson (April 13, 1743 - July 4, 1826 the third President of the United States1801-1809), emphasized that climate data collection could be improved.

A change in our climate however is taking place very sensibly. Both heats and colds are becoming much more moderate within the memory even of the middle-aged. Snows are less frequent and less deep. They do not often lie, below the mountains, more than one, two, or three days, and very rarely a week. They are remembered to have been formerly frequent, deep, and of long continuance. The elderly informed me the earth used to be covered with snow about three months in every year. The rivers, which then seldom failed to freeze over in the course of the winter, scarcely ever do so now. This change has produced an unfortunate fluctuation between heat and cold, in the spring of the year, which is very fatal to fruits. From the year 1741 to 1769, an interval of twenty-eight years, there was no instance of fruit killed by the frost in the neighborhood of Monticello. An intense cold, produced by constant snows, kept the buds locked up till the sun could obtain, in the spring of the year, so fixed an ascendency as to dissolve those snows, and protect the buds, during their development, from every danger of returning cold. The accumulated snows of the winter remaining to be dissolved all together in the spring produced those overflowing of our rivers, so frequent then, and so rare now.

President Jefferson's contribution on climate science remained the most influential in history; he initiated research on major, basic science including climatology.

To you therefore we address our solicitations, and to lessen to you as much as possible the ambiguities of our object, I will venture even to sketch the sciences which seem useful \& practicable for us, as they occur to me while holding my pen. Botany, Chemistry, Zoology, Anatomy, Surgery, Medicine, Natl Philosophy, Agriculture, Mathematics, Astronomy, Geology, Geography, Politics, Commerce, History, Ethics, Law, Arts, Fine arts. Jeffersion as cited by Fulling, 1945:266.

Jefferson was highly influenced by the European Enlightenment thinkers such as John Locke (1632-1704); Charles-Louis Secondat Montesquieu (1689-1755); Isaac Newton (1642-1727); François Quesnay (1694-1774); Guillaume-Thomas Raynal (1713- 1796); JeanJacques Rousseau (1712-1778); Anne-Robert-Jacques Turgot (17271781); François-Marie Arouet Voltaire (1694-1778) etc. Thomas Jefferson was also one of the contributors to the Enlightenment era from North America along with Benjamin Franklin, James Otis, John Adams and others, who directly or indirectly contributed to the fostering of scientific research.

John Tyndall (1820-1893): Noted in 1859 that IR absorption by trace gases is "a perfectly unexplored field of inquiry. Elementary gases, oxygen, nitrogen, and hydrogen, are almost transparent to radiant heat, more complex molecules, such as $\mathrm{H}_{2} \mathrm{O}, \mathrm{CO}_{2}, \mathrm{O}_{3}$ and hydrocarbons, even in very small quantities, absorb much more strongly than the atmosphere itself.... The atmosphere admits of the entrance of the solar heat, but checks its exit; and the result is a tendency to accumulate heat at the surface of the planet. The aqueous vapor constitutes a local dam, by which the temperature at the earth's surface is deepened; the dam, however, finally overflows, and we give to space all that we receive from the sun. Changes in the amount of any of the radiatively active constituents of the atmosphere-water vapor, carbon dioxide, ozone, or hydrocarbons - could have produced all the mutations of climate which the researches of geologists reveal..."

Svante Arrhenius (1859-1927): ${ }^{14}$ Depicted a model of $\mathrm{CO}_{2}$ controlling ice ages and interglacials and discussed that the geometric decline in $\mathrm{CO}_{2}$ causes a linear decrease in temperature. However, industrial emissions were not yet of concern to him. His climate model is often cited, but it is not continuous with modern results or concerns (also cited by Weart ${ }^{15}$ );

"In his 1896 paper, Svante Arrhenius laid the foundation for the modern theory of the greenhouse effect and climate change. The paper is required reading for anyone attempting to model the greenhouse effect of the atmosphere and to estimate the resulting temperature change. Arrhenius demonstrates how to build a radiation and an energy balance model directly from observations. Arrhenius was fortunate to have access to Langley's data, which are some of the 
best radiometric observations ever undertaken from the surface. The successes of Arrhenius'model are many, even when judged by modernday data and computer simulations: the suggestion of the diffusivity factor including its correct numerical value; the remarkably accurate simulation of the total emissivity of the atmosphere which seem to agree within 5\% of modern-day values; the logarithmic dependence of the $\mathrm{CO}_{2}$ radioactive heating effect; and others documented in the text....The main goal of this paper was to estimate the surface temperature increase due to an increase in $\mathrm{CO}_{2}$. Towards this goal, Arrhenius developed a detailed and quantitative model for the radiation budget of the atmosphere and the surface". ${ }^{16}$

\section{Modern era of climate science}

Guy stewart callendar ${ }^{17}$ (1898-1964): Concentrated on rising temperatures, rising fossil fuel consumption, rising $\mathrm{CO}_{2}$ concentrations and a detailed understanding of IR - The Callendar Effect - Climatic change brought about by anthropogenic increases in the concentration of atmospheric carbon dioxide, primarily through the processes of combustion.

"As man is now changing the composition of the atmosphere at a rate which must be very exceptional on the geological time scale, it is natural to seek for the probable effects of such a change. From the best laboratory observations, it appears that the principal result of increasing atmospheric carbon dioxide... would be a gradual increase in the mean temperature of the colder regions of the earth., 3,17,18

Callendar provided new direction to climate science with the evidence from temperature data collected from various metrological stations. He showed the growing trend of global temperature from 1860 to 1940 , which are the first comparative presentation of climate change (Figure 1 or $^{3}$ ).

Roger Randall Dougan Revelle (1909-1991) (in Report of the Environmental Pollution Panel, President's Science Advisory Committee, 1965): By the year 2000, there will be about $25 \%$ more $\mathrm{CO}_{2}$ in our atmosphere than at present. This will modify the heat balance of the atmosphere to such an extent that marked changes in climate, not controllable through local or even national efforts, could occur.

Jule Charney (known as the Charney report) (National Academy of Sciences, Carbon Dioxide and Climate: A Scientific Assessment Report, $\left.{ }^{19}\right)$ : The consensus has been that increasing carbon dioxide will lead to a warmer earth with a different distribution of climatic regimes. Doubling $\mathrm{CO}_{2}$ in models results in 1.5 to $4.5 \mathrm{C}$ warming. Positive feedbacks will increase the warming.

A similar situation was presented in the same year's publication of the Science Journal by Carl Sagan, Owen B. Toon and James B. Pollack in an article titled "Anthropogenic Albedo Changes and the Earth's Climate" where they summarized that:

"The human species has been altering the environment over largegeographic areas since the domestication of fire, plants, andanimals. The progression from hunter to farmer to technologisthas increased the variety and pace more than the geographicextent of human impact on the environment. A number of regionsof the earth have experienced significant climatic changes closelyrelated in time to anthropogenic environmental changes. Plausiblephysical models suggest a causal connection. The magnitudesof probable anthropogenic global albedo changes over the pastmillennia (and particularly over the past 25 years) are estimated.The results suggest that humans have made substantial contributionsto global climate changes during the past several millennia, and perhaps over the past million years; further such changesare now under way. ${ }^{19}$

They also presented how anthropogenic activities changed the global environment. The following figure summarizes the scenario of anthropogenic changes in the environment. (Figure 2).

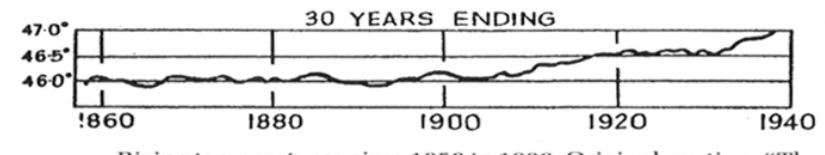

Rising temperatures circa 1858 to 1939. Original caption: "The 30 year moving average from the combined means at Edinburgh, Oxford, Greenwich, De Bilt, Bergen, Oslo, Stockholm, Copenhagen, Wilno sphere through the Ages," Meteorol. Mag. 74 (1939).

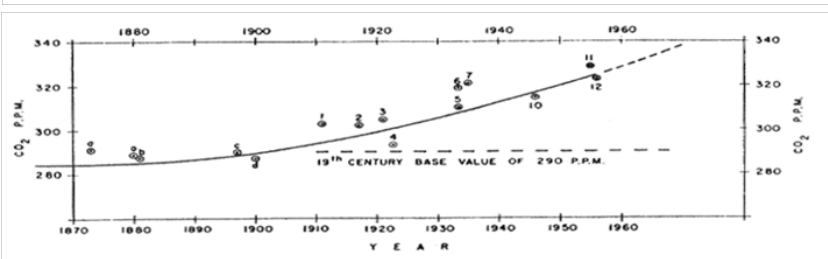

"Amount of $\mathrm{CO}_{2}$ in the free air of the N. Atlantic region, 18701956. Data points indicate individual measurements; the solid line rep Amount of Carbon Dioxide in the Atmosphere," Tellus 10 (1958).

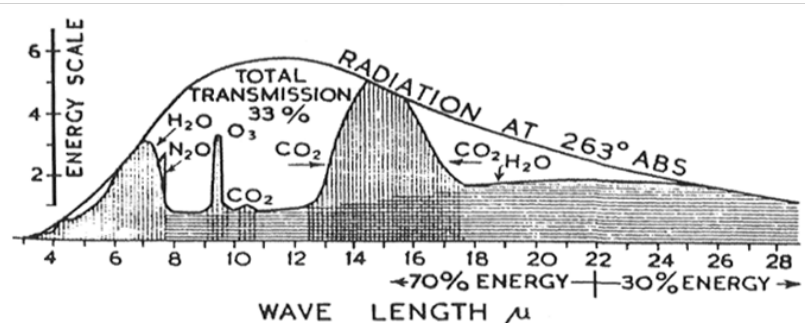

The generalized atmospheric spectrum in infrared wavelengths. Source: G. S. Callendar, "Infra-red Absorption by Carbon Dioxide, with Special Reference to Atmospheric Radiation," Quart. J. Roy. Meteorol. Soc. 67 (1941).

Figure I Guy Stewart Callendar's graphs on Rising Climate, Source: Fleming. ${ }^{3}$

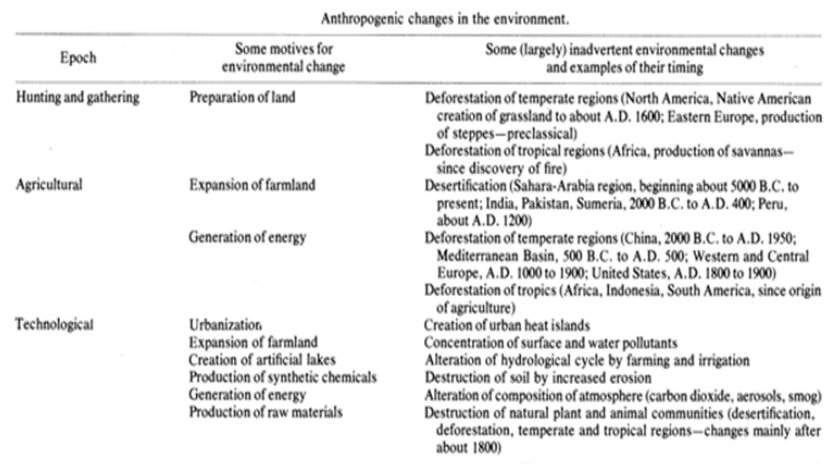

Figure 2 Scenario of anthropogenic changes in the environment, Source: Adopted from Sagan, Toon \& Pollack. ${ }^{23}$ 
As presented above, the environmental problems and issues were well understood by the scientists even before 1900; however, they were largely overlooked. The exploration of the climate change origin, its history, and the contribution of scientists extensively began its focus in the 1950s. There are a large number of publications regarding the concern of global environment by individual authors, groups of authors or in the name of environment conservation. The formation of the International Union for Conservation of Nature (IUCN-1948), and the International Council for Science (ICSU-1931) are exemplary contributors as groups of scientists (further described in chapter three), who extensively contributed to bring climate science to the public agenda. James Rodger Fleming ${ }^{3}$ provides a good historical account of climate change in his book "Historical Perspectives on Climate Change." Similar attempts have been made by the first chair of the Intergovernmental Panel on Climate Change (IPCC) Bert Bolin, ${ }^{4}$ who began to write on the climate change issue in the $1960 \mathrm{~s}$, with the analysis of carbon dioxide and atmosphere and ended with his latest book entitled "A History of the Science and Politics of Climate Change of 2007," before he passed away. Other such attempts can be found in the work of Mathew Paterson (1996), through his book "Global Warming and Global Politics" and Spencer R. Weart's book on "the Discovery of Global Warming. ${ }^{20}$

\section{The milestones on the way to understanding climate changes}

The following are milestones on the way to understanding changes of the greenhouse effect of the earth's atmosphere (until 1967 when the first, full, three-dimensional global circulation model study for doubled $\mathrm{CO}_{2}$ concentration appeared). The table summarizes the scientist's concern in the specific subject on climate change from 1842 as milestone to 1924 and the theoretical shift. Table 1 shows climate change theories as classified by Brooks (1950) as cited by Fleming, 1998. Table 2 depicts the similar story in different order.

Table I Climate change theories as classified by Brooks (1950) as cited by Fleming ${ }^{3}$

\begin{tabular}{|c|c|}
\hline Climate change theories & The theorists and scientists \\
\hline Changes in elements of the Earth's orbit & $\begin{array}{l}\text { Adhémar (1842), Croll }(1864,1875) \text {, Drayson (1873), Ekholm (1901), Spitaler } \\
\text { (1907), Milankovic }(1920,1930,1941)\end{array}$ \\
\hline Changes of solar radiation & $\begin{array}{l}\text { Dubois (1895), Simpson }(1930,1934,1939-40) \text {, Himpel (1937), Hoyle and } \\
\text { Lyttleton (1939) }\end{array}$ \\
\hline Lunar-solar tidal influences & Pettersson (1914) \\
\hline Elevation of land masses - mountain building & $\begin{array}{l}\text { Lyell (1830-33), Wright (1890), Ramsay (1909-10, 1924), Brooks (1926, } \\
\text { 1949) }\end{array}$ \\
\hline Changes in atmospheric circulation & Harmer (1901, 1925), Gregory (1908), Hobbs (1926), Flint and Dorsey (1945) \\
\hline Changes in oceanic circulation & Croll (1875), Hull (1897), Chamberlin (1899), Brooks (1925), Lasareff (1929) \\
\hline Changes in continent-ocean distribution & $\begin{array}{l}\text { Czerney (1881), Harmer }(1901,1925), \text { Gregory (1908), Brooks (1926), Willis } \\
\text { (1932) }\end{array}$ \\
\hline Changes in atmospheric composition & $\begin{array}{l}\text { Arrhenius (1896), Chamberlin }(1897,1899) \text {, Ekholm (1901), Callendar (1938, } \\
\text { 1939) }\end{array}$ \\
\hline Volcanic dust in the atmosphere & Humphreys $(1913,1920)$, Abbot and Fowle (1913) \\
\hline Cosmic dust theory & Hoyle and Lyttleton (1939), Himpel (1947) \\
\hline Sunspot theory & Czerny (1881), Huntington (1915), Huntington and Visher (1922) \\
\hline Polar migration and continental drift theory & Kreichgauer (1902), Wegener (1920), Köppen and Wegener (1924) \\
\hline
\end{tabular}

Table 2 Source:Adopted from Grassl (2007) with permission on 04/03/2010)"

\begin{tabular}{|c|c|c|c|c|}
\hline Scientific Breakthroughs & Scientist(s) & Year & Journal/Book & (Book) Title \\
\hline $\begin{array}{l}\text { Indication that the } \\
\text { atmosphere acts like a } \\
\text { shield that keeps heat in the } \\
\text { system }\end{array}$ & Jean Baptiste & 1824 & $\begin{array}{l}\text { Annales de Chemie et de } \\
\text { Physique 27: I36-167 } \\
\text { Mémoires de l'Académie } \\
\text { Royale } \\
\text { des Sciences 7: 569-604 }\end{array}$ & $\begin{array}{l}\text { Remarques générales sur les } \\
\text { températures du globe terrestre et des } \\
\text { espaces planétaires } \\
\text { Mémoire sur les temperatures du globe } \\
\text { terrestre } \\
\text { et des espaces planétaires }\end{array}$ \\
\hline $\begin{array}{l}\text { First full description of the } \\
\text { greenhouse effect }\end{array}$ & John Tyndall & 1863 & $\begin{array}{l}\text { Proceedings of the Royal } \\
\text { Institute of Great Britain 3: I58 }\end{array}$ & $\begin{array}{l}\text { On the transmission of heat of different } \\
\text { qualities through gases of different } \\
\text { kinds }\end{array}$ \\
\hline $\begin{array}{l}\text { Deforestation as a cause for } \\
\text { climate change }\end{array}$ & Eduard Brückner & 1890 & \multicolumn{2}{|c|}{$\begin{array}{l}\text { Klimaschwankungen seit } 1700 \text { nebst Bemerkungen über die } \\
\text { Klimaschwankungen der Diluvialzeit. Geographische Abhandlungen. Edited } \\
\text { by E. D. Penck.Vienna: Hölzl }\end{array}$} \\
\hline $\begin{array}{l}\text { First warming rate for } \\
\text { doubled } \\
\mathrm{CO}_{2} \text { concentration }\end{array}$ & Svante Arrhenius & 1896 & $\begin{array}{l}\text { Philosophical Magazine } \\
\text { series 5: 237-276 }\end{array}$ & $\begin{array}{l}\text { On the influence of carbonic acid in } \\
\text { the air upon the temperature of the } \\
\text { ground }\end{array}$ \\
\hline
\end{tabular}




\begin{tabular}{|c|c|c|c|c|}
\hline $\begin{array}{l}\text { First full link from } \mathrm{CO}_{2} \\
\text { concentration } \\
\text { change via gas absorption of } \\
\text { heat radiation } \\
\text { to surface temperature } \\
\text { change }\end{array}$ & Guy S. Callendar & 1938 & $\begin{array}{l}\text { Quarterly Journal of the } \\
\text { Royal Meteorological Society } \\
64: 223-240\end{array}$ & $\begin{array}{l}\text { The artificial production of carbon } \\
\text { dioxide and } \\
\text { its influence on temperature }\end{array}$ \\
\hline $\begin{array}{l}\text { First radioactive transfer } \\
\text { calculations of } \\
\text { an enhanced greenhouse } \\
\text { effect }\end{array}$ & Gilbert N. Plass & 1956 & Tellus 8: |40-154 & $\begin{array}{l}\text { The carbon dioxide theory of climate } \\
\text { change }\end{array}$ \\
\hline $\begin{array}{l}\text { First equilibrium model } \\
\text { study for } \\
\text { doubled } \mathrm{CO}_{2} \text { concentration }\end{array}$ & $\begin{array}{l}\text { Syukuro Manabe, } \\
\text { Fritz Möller }\end{array}$ & 1967 & $\begin{array}{l}\text { Monthly Weather Review 89: } \\
503-532\end{array}$ & $\begin{array}{l}\text { On the radiation equilibrium and heat } \\
\text { balance } \\
\text { of the atmosphere }\end{array}$ \\
\hline
\end{tabular}

These tables show that the concern of climate change is not a new phenomenon. As previously discussed, climate science and concern about it primarily began in the Greek era; however, it took hundreds of years to become a fully accepted science. 1972 was the milestone year for the institutionalization of climate science through the first World Conference on Global environment, which recommended establishing the United National Environment Program. Similarly, the Club of the Rome also published its most authentic report "The Limits to Growth" ${ }^{21}$ which draws global attention to the global climate. There is no direct challenge on the research outcome of the Rome Club. The "Limits to Growth" report states that if the present growth trends in world population, industrialization, pollution, food production and resource depletion continue unchanged, the limits to growth on this planet will be reached sometime within the next one hundred years (Bhandari 2012). The most probable result will be a rather sudden and uncontrollable decline in both population and industrial capacity. This was a second shock after Rachel Carson's book Silent Spring (1962), which largely drew the attention of the general public regarding the seriousness of global climate change (Brechin and Bhandari 2011).

\section{The United Nations-major role players on climate change issues}

Having growing concerns and evidence of global climate change, UNEP continued its consultation with the scientific and government agencies to reach a mutual understanding. As a follow up to previous conferences and public concern, in 1977, at the request of its Governing Council UNEP convened a meeting of experts on the ozone layer which formulated a draft World Plan of Action on the Ozone Layer. The Plan of Action, adopted by the Governing Council at its eighth session, for research into and assessment of the state of the atmospheric ozone layer and the consequences of its modification was to be implemented by UN bodies, specialized agencies, international, national, intergovernmental and non-governmental organizations and scientific institutions ${ }^{22}$ and in 1979, the first World Climate Conference was organized by the World Metrological Organization (the details regarding the role of organization is discussed in chapter three). As we noted above, the Charney report was also published in 1979 along with the Sagan, Toon \& Pollack ${ }^{23}$ groundbreaking research showing anthropogenic action as a major source of climate change. Following up the same sequence at its seventh session (Geneva, October 1984), the COOL called the attention of all countries and economic organizations not yet reporting production figures for CFCs 11 and 12, as well as for other halocarbons, to the need for reporting pertinent chemical production, release and usage data, including the more detailed data on production and uses needed for socioeconomic analyses. ${ }^{22}$.

Similarly, in 1985, from October 9-15, a joint UNEP/WMO/ICSU Conference was convened in Villach (Austria) to assess the role of increased carbon dioxide and other radioactive constituents of the atmosphere (collectively known as greenhouse gases and aerosols) on climate changes and associated impacts. The conference concluded that the other greenhouse gases reinforce and accelerate the impact because of $\mathrm{CO}_{2}$ alone. As a result of the increasing concentrations of greenhouse gases, it is now believed that in the first half of the next century, a rise of global mean temperature could occur that is greater than any in man's history. ${ }^{24}$ This conference pin pointed the need of an international organization to assess the impact of climate change processes.

However, the need for an international agency was highlighted by Vladimir Zworykin in 1945, which was largely ignored by the scientists. Zworykin states:

The eventual goal to be attained is the international organization of means to study weather phenomena as global phenomena and to channel the world's weather, as far as possible, in such a way as to minimize the damage from catastrophic disturbances, and otherwise to benefit the world to the greatest extent by improved climatic conditions where possible (Vladimir Zworykin 1945 as cited by Fleming in The Wilson Quarterly (1976 and 2007: 65).

As result of this, the Villach conference and several others, the ENEP and WMO established the Intergovernmental Panel on Climate Change (IPCC) in 1988. Since then, the IPCC has been playing an important role in producing such knowledge.

The scientists, internationals organizations, governments and governmental organizations highly acknowledge the role of the IPCC. The United Nations Educational, Scientific and Cultural Organization: $\mathrm{UNESCO}^{25}$ states that:

Since the establishment of the Intergovernmental Panel on Climate Change (IPCC), the scientific understanding of climate change has much improved. In their Fourth Report, published in 2007: (IPCC, 2007), the IPCC concluded that:

Global warming is 'undeniable': 11 of the last 12 years were among the 12 warmest years since records have been kept (in 1850). Almost all of the observed temperature rise during the second half of the 
twentieth century is 'very probably' due tohuman activity. The increase in temperature projected for 2100 will be between 2 and $4.5^{\circ} \mathrm{C}$, with a doubling of the concentrations of carbon dioxide compared to preindustrial levels. These 'best estimates' are

averages, in a broader range of 1.1 to $6.4{ }^{\circ} \mathrm{C}\left(1.4\right.$ to $5.8{ }^{\circ} \mathrm{C}$, in the previous report of 2001). All scenarios predict a reduction of sea ice in the Artic and Antarctica.It is highly probable that, in the future, extreme weather events such as heat waves and heavy precipitation will become more frequent and that tropical hurricanes will become more intense. In 2005, the atmospheric concentration of carbon dioxide (the most important greenhouse gas) largely exceeded the concentrations of the past 650,000 years. Past and future $\mathrm{CO}_{2}$ emissions will continue to contribute to global warming and rising sea levels for more than a millennium..$^{25}$

\section{Conclusion}

This paper describes a brief outline of what is climate science, how the concept was emerged and why it is the mainstream subject of the contemporary world.The climate science (and change) has a long history, which can be traced from Greek society, began to receive attention during the enlightenment era, slowly in $19^{\text {th }}$ century and accelerated in the $20^{\text {th }}$ century. The growth of international scientific agencies dealing with the global environment began to accelerate from the beginning of the $20^{\text {th }}$ century and still continues. The following figure adopted from Meyer et al. ${ }^{26}$ provides the growing trend of international scientific agencies on global environment.Figure 3 shows the growth of international scientific organizations from 18801990 (Adopted from Meyer et al. ${ }^{26}$ ).

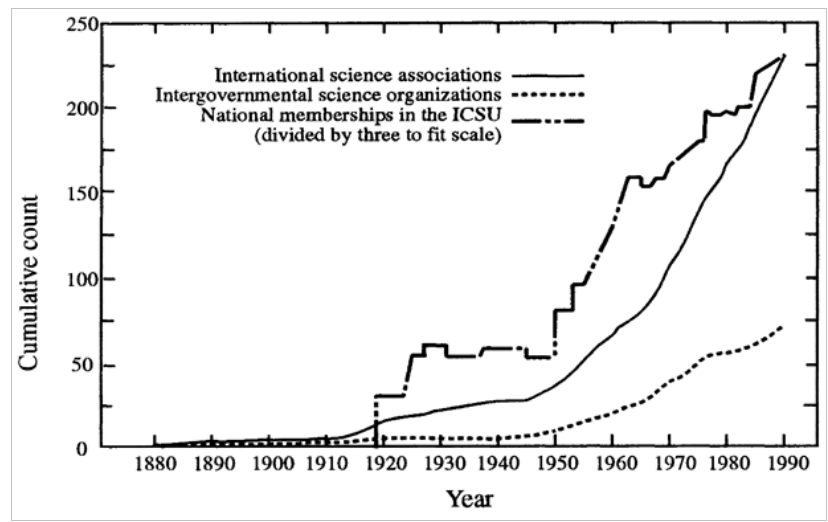

Figure 3 Scenario of anthropogenic changes in the environment, Source: Adopted from Sagan, Toon \& Pollack [23].

Meyer et al. [26] have analyzed that trend from 1880 to 1990 , which provides a clear indication that the concern regarding global environment is not a new phenomenon. However, the major attention began in the 1950s as we explored in above section.

Since the inception of the IPCC in 1988 and the publication of the first assessment report in 1990, climate change has been seen as common global agenda. The detection of climate change takes several years and is a critical process. Schindler [27] gives an outline of how complicated the climate change research is.
"To a patient scientist, the unfolding greenhouse mystery is far more exciting than the plot of the best mystery novel. But it is slow reading, with new clues sometimes not appearing for several years. Impatience increases when one realizes that it is not the fate of some fictional character, but of our planet and species, which hangs in the balance as the great carbon mystery unfolds at a seemingly glacial pace". ${ }^{27}$

\section{Acknowledgement}

The author would like to thank professors Steven R. Brechin, John Mathiason, Keshav Bhattarai and Ms. Prajita Bhandari for their insightful thoughts and comments on the paper. Without their support this research would have been impossible. He would also like to have a special thanks to Prajita, Manaslu, Prameya and Kelsey for their feedback on content and language. Thank to Ms. Tatjana Capar of Ology Journals, Kft., who supported me in the publication process. Thanks to all readers as well.

\section{References}

1. Lakatos I. History of Science and Its Rational Reconstructions. Proceedings of the Biennial Meeting of the Philosophy of Science Association. (1970);1:91-136.

2. Chester RL. Origin of the Word Climate.Science. 1954;120(3113):355

3. Fleming JR. Historical Perspectives on Climate Change, Oxford University Press, New York/ Oxford, USA. ISBN: 0-19.-507870-5. 1998.

4. Bolin B. A History of the Science and Politics of Climate Change, The Role of the Intergovernmental Panel on Climate Change, Cambridge University Press, USA. 2007;1-275.

5. Dunne J. Back to the Rough Ground: 'Phronesis' and 'Techne' in Modern Philosophy and in Aristotle. Notre Dame, Indiana: University of Notre Dame Press, USA. ISBN 978-0-2680-0689-1. 1997.

6. Damon AY. Bowing to Your Enemies: Courtesy, Budo and Japan, Philosophy East \& West. 2009;59(2):188-215.

7. https://ojs.uwindsor.ca/ojs/leddy/index.php/phaenex/article/ download/226/233

8. Zimmerman BJ. Self-regulated learning and academic achievement: An overview. Educational Psychologist. 1990:25(1):3-17.

9. http://www.meteohistory.org/2004polling_preprints/docs/abstracts/ fleming_abstract.pdf.

10. http://unesdoc.unesco.org/images/0018/001818/181893E.pdf

11. Karl MK. Montesquieu: Possibilistic Political Geographer. Annals of the Association of American Geographers. 1968;58(3):557-574.

12. http://www.creatorix.com.au/philosophy/t06/t06f13.html

13. Arrhenius S. On the influence of carbonic acid in the air upon the temperature of the ground. Philosophical Magazine and Journal of Science. 1896;41(251):237-276.

14. Weart SR. The discovery of global warming, Cambridge, Mass, Harvard University Press, USA. 2003.

15. Ramanathan V, Vogelmann MA. Greenhouse Effect, Atmospheric Solar Absorption and the Earth's Radiation Budget: From the ArrheniusLangley Era to the 1990s. Ambio. 1997;26(1):38-46.

16. Callendar GS. The artificial production of carbon dioxide and its influence on temperature. Quarterly Journal of the Royal Meteorological Society. 1938;64:223-240. 
17. Fleming JR. The Callendar Effect: The life and work of Guy Stewart Callendar (1898-1964), the scientist who established the carbon dioxide theory of climate change. Boston, American Meteorological Society. 2007.

18. http://www.atmos.ucla.edu/ brianpm/download/charney_report.pdf

19. Spencer RW. The Discovery of Global Warming, Harvard University Press, USA. 2008.

20. http://www.facebook.com/topic.php?uid=9364228327\&topic $=4478$.

21. www.unep.org/.../ccol8-5-related_activities_to_work_of_cc.86-02-24. doc.

22. Sagan C, Toon OB, Pollack JB. Anthropogenic Albedo Changes and the Earth's Climate. Science. 1979;206(4425):1363-1368.
23. http://www.icsu-scope.org/downloadpubs/scope29/statement.html.

24. http://unesdoc.unesco.org/images/0018/001818/181893E.pdf.

25. Meyer JW,Frank DJ, Ann H, Evan S,Tuma NB. The Structuring of a World Environmental Regime, 1870-1990. International Organization. 1997;51(4):623-651.

26. Schindler David W. "The Mysterious Missing Sink" Nature398: 105-106, also inShapin, Steven and Arnold Thackray (1974). Prosopography as a research tool in history of science: The British scientific community, 17001900. History of Science. 1999;12:1-28 